(C) Elsevier/INRA

Note

\title{
An autosomal trisomy in cattle
}

\author{
MB Lioi ${ }^{1}$, MR Scarfi ${ }^{2}$, D Di Berardino ${ }^{3}$ \\ ${ }^{1}$ University of Basilicata, Department of Animal Production, \\ Via N Sauro 85, 85100 Potenza; \\ ${ }^{2}$ CNR-IRECE, 80124 Naples; \\ ${ }^{3}$ University of Naples, Department of Animal Production, 80055 Portici, Italy
}

(Received 4 November 1994; accepted 12 June 1995)

\begin{abstract}
Summary - Karyotyping of a malformed Italian Friesian calf revealed one additional autosome in all the lymphocyte metaphases studied. This chromosome has been identified by G-banding using trypsin and giemsa staining (GTG) and R-banding by lateincorporation of BrdU and acridine orange staining (RBA) banding techniques, as probably being chromosome number 20, according to the International System for Cytogenetic Animals nomenclature (ISCNDA). The calf presented deformations of anterior and posterior legs, an opistotonous neck, lower brachygnathia, bilateral blindness and absence of external genitalia. The condition also appears to be associated with chromosome instability.

autosomal trisomy / chromosome / anomaly / cattle
\end{abstract}

Résumé - Une trisomie autosomique chez le bovin. L'analyse caryotypique d'un veau anormal de race Frisonne italienne a montré la présence d'un autosome surnuméraire dans toutes les métaphases étudiées. Le chromosome a été identifié par les techniques de bandes $G$ et $R$; il s'agit probablement du chromosome 20, en accord avec la nomenclature ISCNDA. Le veau présentait des déformations aux membres inférieurs et supérieurs, un cou opistotonique, une brachygnathie inférieure, une cécité bilatérale et l'absence d'organes génitaux externes. L'anomalie semble aussi associée à une fragilité des chromosomes.

trisomie autosomique / chromosome / anomalie / bovin

\section{INTRODUCTION}

Autosomal trisomy is occasionally compatible with life and usually associated with phenotypic abnormalities. Since the discovery of Down's syndrome in humans, chromosome aberrations have received increasing attention in various pathological conditions. 
Cytogenetic studies of abnormal phenotypes in domestic animals are rare compared to those in humans. Trisomy has been occasionally reported in cattle (Eldridge, 1985). Previous studies of non-banded chromosomes have reported trisomy in association with lethal brachygnathia (Mori et al, 1969; Dunn and Johnson, 1972). Herzog et al (1977) found trisomy of autosome 17 associated with this defect in 16 calves. In other studies the extra chromosome was not always clearly identified (Long, 1984; Schmutz et al, 1987). The first case of a viable calf trisomic for chromosome 22 was found by Mayr et al (1985). Trisomy 24 has been reported by Makinen et al (1987). This paper reports an autosomal trisomy in cattle associated with an abnormal phenotype.

\section{MATERIALS AND METHODS}

Peripheral blood from the abnormal calf and its dam, both of the Italian Friesian breed, was cultured for $72 \mathrm{~h}$ at $37^{\circ} \mathrm{C}$ in RPMI 1640 medium (Flow, Dutch modification) supplemented with $0.1 \mathrm{ml} \mathrm{L}$-glutamine (Gibco), $20 \%$ of foetal calf serum (Gibco) and $0.1 \mathrm{ml}$ Pokeweed mitogen (Gibco). For RBA-banding BUdR $(10 \mu \mathrm{g} / \mathrm{ml}$ final concentration) was added $6.5 \mathrm{~h}$ before the end of the culturing time. All the cultures were exposed to colcemid for $1 \mathrm{~h}$. The cells were swollen in a hypotonic solution $(0.075 \mathrm{M} \mathrm{KCl})$ for 20 min and fixed in 3:1 methanol/acetic acid. Air-dried preparations were stained with Giemsa (5\% in Sorensen buffer, $\mathrm{pH} 7.0$ ) for 10 min. G-banding using trypsin and giemsa staining (GTG) and R-banding by late-incorporation of $\mathrm{BrdU}$ and acridine orange staining (RBA) were performed according to standard methods.

\section{RESULTS}

The calf's dam was 5 years old, phenotypically and karyologically normal, and had already given birth to phenotypically normal calves. Insemination was by a genetically proven sire. The 1-week-old calf presented lower brachygnathia, deformations of anterior and posterior legs, an opistotonous neck, bilateral blindness and absence of external genitalia.

Cytogenetic analysis of the malformed calf revealed one additional autosome constantly present in all the cells examined. The GTG and RBA banding techniques were applied to identify the extra chromosome, but, because of the premature death of the calf, it was not possible to collect more blood for a more detailed cytogenetic analysis. However, on the basis of the small amount of material available, the additional chromosome was tentatively identified as $\mathrm{n} 20$.

Figure 1A presents the GTG-banded karyotype $(2 n=61, \mathrm{XY},+20$ ?), while figures $1 \mathrm{~B}$ and $1 \mathrm{C}$ present chromosomes $\mathrm{n} 19,20$ and 21 from other GTG- and RBA-banded karyotypes, respectively.

In the malformed calf, abnormal cells with chromosome and chromatid breaks were observed with a frequency of $9.3 \%$ (4 out of 43 metaphase spreads) in the conventional cultures and $39 \%$ (15 out of 41 metaphase spreads) in those with BUdR incorporation. These data suggest that the trisomic condition might also be associated with a kind of chromosome instability, as indicated by the high 

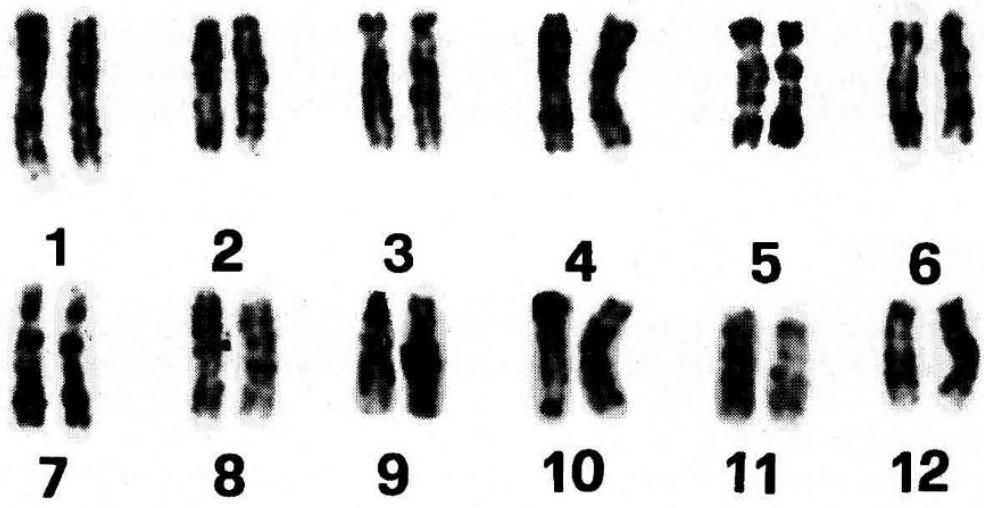

11

12
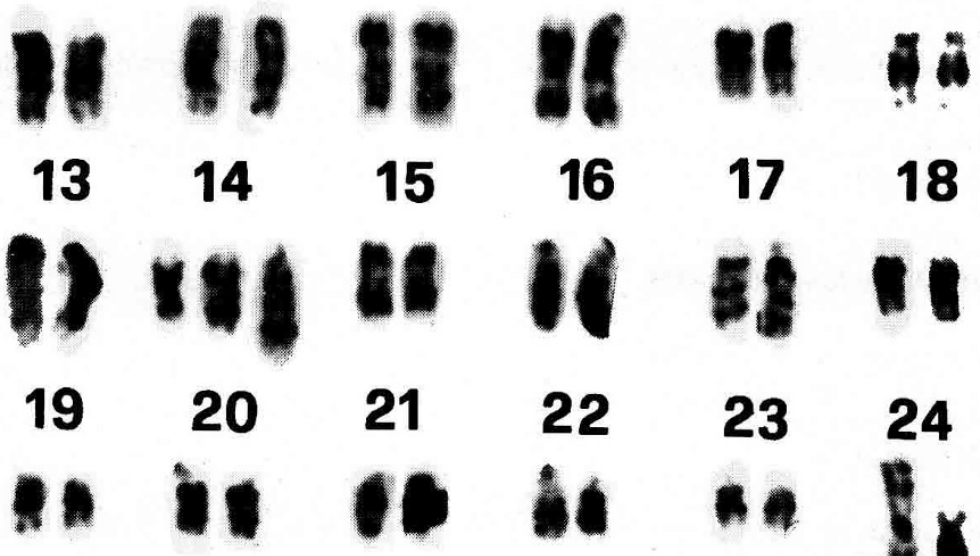

23

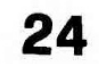

25

26

27

28

a

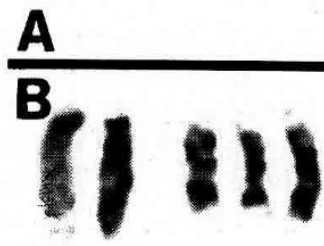

$19 \quad 20$
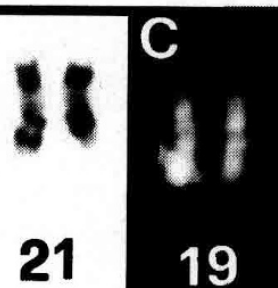

19

20

21

Fig 1. A. GTG-banded karyotype of the malformed calf showing trisomy of autosome n 20. Chromosome pairs n 19, 20 and 21 from another GTG-banded karyotype (B) and RBA-banded karyotype (C). 
frequency of abnormal cells found in the conventional cultures. Moreover, in the BUdR-exposed cultures the level of abnormal cells was found to be nearly 4 times higher compared to the conventional ones. A more detailed cytogenetic analysis (SCE test, micronucleus test) would necessary for a better understanding of the chromosome instability condition.

\section{DISCUSSION}

Studies of trisomy in cattle are not numerous. Firstly, there are practical difficulties in finding abnormal animals and studying them before they die or are eliminated by the breeders. Secondly, the liveborn incidence of trisomy represents a relatively small proportion of all trisomic conceptuses probably because most autosomal aneuploidies are eliminated prior to embryo implantation (Hare et al, 1980). Thirdly, the intensity of selection practised in livestock may have lowered the incidence of trisomy in comparison to that in humans.

The present study confirms the need to extend cytogenetic investigations of other cases of congenital malformations and to undertake populations studies, in order to establish the real frequencies of specific or general chromosome aberrations in livestock species.

\section{ACKNOWLEDGMENTS}

Research supported by MURST (60\%).

\section{REFERENCES}

Dunn HO, Johnson RH (1972) A 61, XX cell line in a calf with extreme brachygnathia. J Dairy Sci 55, 524-526

Eldridge FE (1985) Cytogenetics of Livestock (AVI) Publishing CO Inc, Westpoint, CT, USA

Hare WCD, Singh EL, Betteridge KJ et al (1980) Chromosomal analysis of 159 bovine embryos collected 12 to 18 days after estrus. Can J Genet Cytol 22, 615-626

Herzog A, Höhn H, Rieck GW (1977) Survey of recent situation of chromosome pathology in different breeds of german cattle. Ann Génét Sél Anim 9 (I), 471-491

ISCNDA (1990) International system for cytogenetic nomenclature of domestic animals (Di Berardino D, Hayes H, Fries R, Long S, eds). Cytogenet Cell Genet 53, 65-79

Long SE (1984) Autosomal trisomy in a calf. Vet Rec 115, 16-17

Mayr B, Krutzler H, Auer H, Schleger W, Sasshofer K, Glawischnig E (1985) A viable calf with trisomy 22. Cytogenet Cell Genet 39, 77-79

Makinen A, Ilkka A, Matti A (1987) Autosomal trisomy in a heifer. Acta Vet Scand 28, $1-8$

Mori M, Sasaki M, Makino S, Ishikawa T, Kawata K (1969) Autosomal trisomy in a malformed newborn calf. Proc Jpn Acad 45, 955-957

Schmutz SM, Coates JW, Rousseaux CG (1987) Chromosomal trisomy in an anomalous bovine fetus. Can Vet J 28, 61-62 